\title{
Using water level and temperature time series to improve hydrogeological parameterization in a complex alluvial system
}

\section{Utilizzo dei dati di livello e temperatura dell'acqua di falda per migliorare la parametrizzazione idrogeologica in un sistema alluvionale complesso}

Luca Vettorello, Andrea Sottani

Riassunto: Un nuovo campo pozzi è stato progettato nell'alta pianura settentrionale della provincia di Padova, con l'obiettivo di raggiungere una portata complessiva di circa $2 \mathrm{~m}^{3} / \mathrm{s}$, al fine di contribuire in modo rilevante all'approvvigionamento di acqua potabile a scala regionale. La falda freatica locale è un sistema alluvionale altamente permeabile, collegato idraulicamente al fiume Brenta, una delle più importanti fonti di ricarica delle acque sotterranee dell'intero bacino idrogeologico, e al lago di Camazzole, una ex cava. Questo lago si approfondisce al di sotto del livello freatico ed è direttamente collegato all'acquifero circostante e indirettamente al fiume, formando un equilibrio idraulico a 3 elementi. Al fine di valutare la sostenibilità dello sfruttamento delle acque sotterranee, questo caso di studio ha richiesto un'analisi approfondita della risorsa idrogeologica, concentrandosi sulla stima dei valori e della distribuzione della conducibilità idraulica. Sin dalla prima fase dello studio è stata necessaria una simulazione numerica, per pianificare le successive attività di campo e fornire una rappresentazione approssimativa dell'abbassamento prevedibile nell'acquifero in pompaggio, anche se il modello iniziale presentava un livello di incertezza molto elevato. Prima delle prove di pompaggio non erano disponibili dati sperimentali, quindi una distribuzione omogenea di conducibilità idraulica è stata assegnata in via preliminare all'intera mesh, facendo riferimento a un singolo valore bibliografico disponibile per la falda acquifera. Dopo l'interpretazione analitica dei test di pompaggio, sono stati stimati diversi valori puntuali di conducibilità idraulica, ma la distribuzione del parametro rimaneva ancora difficilmente determinabile, a causa della complessità del contesto idrogeologico e della non unicità delle possibili inter-

Keywords: hydraulic properties, heat transport modeling, groundwater/ surface-water relations.

Parole chiave: Proprietà idrodinamiche, modellazione del trasporto di calore, relazioni acque sotterranee/superficiali.

\section{Luca VETTORELLO 莑”}

Sinergeo Srl - Vicenza, Italy

lvettorello@sinergeo.it

\section{Andrea SOTTANI \\ Sinergeo Srl - Vicenza, Italy \\ asottani@sinergeo.it}

Ricevuto/Received: 14 October 2019-Accettato/Accepted: 19 December 2019 Pubblicato online/Published online: 20 December 2019

This is an open access article under the CC BY-NC-ND license: http://creativecommons.org/licenses/by-nc-nd/4.0/

(C) Associazione Acque Sotterranee 2019 polazioni spaziali. La disponibilità di osservazioni del livello di falda su larga scala ha permesso di calcolare una serie di campi di conducibilità idraulica attraverso il metodo dei pilot points, integrando i risultati dei test di pompaggio ed estendendo la caratterizzazione idraulica su un dominio più ampio. Il modello numerico è stato infine calibrato con gli andamenti monitorati della temperatura delle acque sotterranee, riproducendo l'interazione tra il lago e la falda freatica attraverso una simulazione del trasporto di calore. La distribuzione della conducibilità idraulica risultante è stata considerevolmente perfezionata, specialmente all'interfaccia tra il lago e la falda acquifera, e la parametrizzazione è stata ulteriormente validata usando il calore come tracciante delle acque sotterranee.

Abstract: A new pumping station was designed in the northern bigh plain of the province of Padua (Veneto region, north-eastern Italy), aiming to reach an overall abstraction rate of about $2 \mathrm{~m}^{3} / \mathrm{s}$, in order to relevantly contribute to the regional drinking water supply. Local unconfined aquifer is a bighly permeable alluvial system, bydraulically connected to the Brenta river, one of the most important groundwater recharging sources of the entire bydrogeological basin, and the Camazzole lake, a former open-pit mine. This lake deepens below the water table and is directly connected to the surrounding phreatic aquifer and indirectly to the river, forming a 3-element bydraulic equilibrium. In order to evaluate the sustainability of the groundwater exploitation, this case study required an in-depth analysis of the bydrogeological resource, focusing on the estimation of hydraulic conductivity values and distribution. A numerical simulation was needed since the first step of the study, to plan the following field activities and provide a rough representation of the expectable drawdown in the pumped aquifer, even if the initial model had a very high level of uncertainty. Before the pumping tests no experimental data were available, so a homogeneous distribution of bydraulic conductivity was preliminarily assigned to the entire mesh, referring to a single bibliographic value available for the aquifer. After the analytical interpretation of pumping tests, different punctual values of hydraulic conductivity were estimated, but the parameter field was still very difficult to define, due to the complexity of the hydrogeological context and the non-uniqueness of the possible spatial interpolations. The availability of groundwater level observations at a larger scale allowed to calculate a set of hydraulic conductivity fields through the pilot points method, integrating the pumping tests results and extending aquifer characterization to a wider domain. The numerical model was finally calibrated with groundwater temperature monitored trends, reproducing the interaction between the lake and the phreatic aquifer through a heat transport simulation. The resulting bydraulic conductivity distribution has been considerably refined, especially at the interface between the lake and the aquifer, and the parameterization has been further validated using heat as a groundwater tracer. 


\section{Introduction}

Hydraulic conductivity characterization is one of the most important and challenging task in hydrogeology, one of the key aspects to build a representative numerical model to simulate flow and transport processes in groundwater (Sudicky 1986; Moench et al. 2001; Zhang et al. 2007). Data interpretation techniques offer very powerful tools to estimate hydraulic conductivity and other parameters with inverse modeling approaches (Doherty 2015), but often there are very few observations available to validate the simulation results and verify the estimation reliability. While pumping tests and hydraulic head measurements are commonly used to estimate hydraulic conductivity, temperature monitoring data seem to be more rarely considered for this specific application.

Heat has been commonly used as a natural tracer to calculate the flow exchanges between aquifers and surface water bodies (Constantz and Stonestrom 2003; Anderson 2005; Constantz 2008) and several case studies show interesting and consistent model results (Hunt et al. 1996; Bravo et al. 2002; Su et al. 2004). Thermal trends are easily recorded with standard groundwater dataloggers, so no dedicated instrumentation is required, and often these time series are coupled to level monitoring values. A limiting factor is the existence of relevant temperature differences between an aquifer and a surface water body connected to it, or an aquifer and an anthropic system (e.g. borehole heat exchangers).

In this case study, lake and groundwater temperature recordings proved to be very useful to improve lakebed and aquifer hydraulic parameterization, offering an additional possibility to calibrate the numerical model.

\section{Study area}

The study area is located in north-eastern Italy, in the province of Padua (Fig. 1a), very close to the Brenta river, one of the main river of the Veneto region and an element of primary importance in terms of groundwater recharge. The local aquifer is a very conductive alluvial system, hydraulically connected to the Brenta river itself; hydraulic head values vary significantly from north to south and consequently the aquifer is either recharged or drained by the river within the study area. The case study is located in the middle of the transition zone, where groundwater level and the river stage show small to negligible differences.

A new pumping station was designed to contribute to the regional drinking water supply, planning to obtain in this area an overall abstraction rate of about $2 \mathrm{~m}^{3} / \mathrm{s}$. 8 pumping wells were already available (yellow dots in Figure 1b) and 9 new wells were drilled from September 2016 to June 2017 (red dots in Figure 1b), between the Brenta river and the Camazzole lake, a former open-pit mine with an area of about $0.42 \mathrm{~km}^{2}$, at a close distance of $150-200 \mathrm{~m}$ from the river bank. This lake drains water from the phreatic aquifer on the northwestern border and recharges it along the southwestern side (Fig. 1b), as confirmed by previous studies on the same site (Dal Prà 1999).

The pumping wells are screened in the phreatic aquifer,

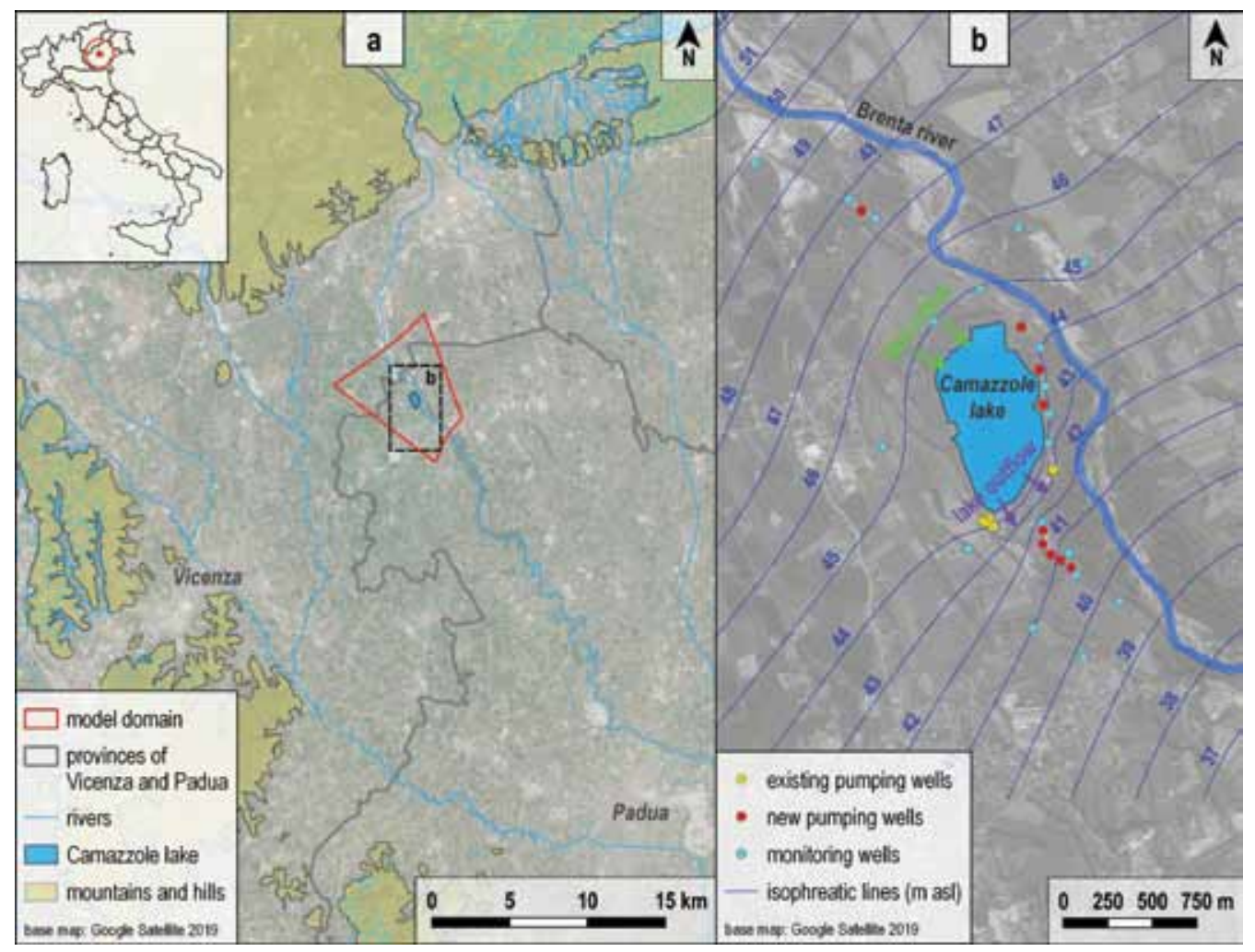

Fig. 1 - Site location (a) and hydrogeological context (b); groundwater levels are expressed in meters above sea level ( $m$ asl).

Fig. 1 - Ubicazione del sito (a) e contesto idrogeologico (b); i livelli di falda sono espressi in metri sul livello del mare ( $\mathrm{m} \mathrm{slm})$. 
which is mainly made of gravel and sand, with a thickness ranging from about 22 to $32 \mathrm{~m}$, as showed in Figure 2. A deeper sandy layer, a confined aquifer with lower hydraulic transmissivity, is separated by an impermeable layer made of clay materials.

Figure 3 reports water level and temperature values monitored during summer 2018 in the river, in the lake basin and in the phreatic aquifer. The river (Fig. 3a) shows a very rapid response to recharge events from rainfall and a daily thermal oscillation; on the other hand, the lake (Fig. 3b) demonstrates a more smoothed water level trend and a

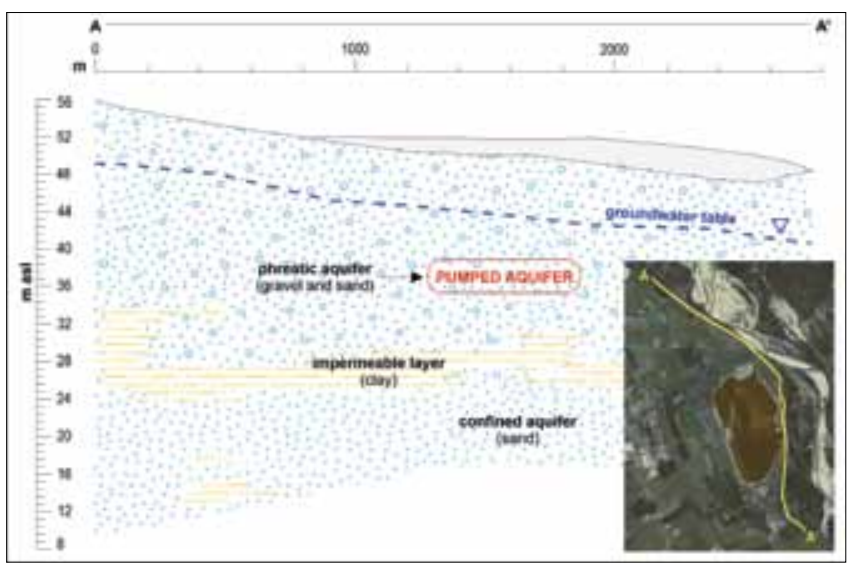

Fig. 2 - Lithostratigraphic cross-section with groundwater table.

Fig. 2 - Sezione litostratigrafica con livello freatico. temperature range from about $8^{\circ} \mathrm{C}$ to about $27^{\circ} \mathrm{C}$, following the medium air temperature. Water level variations in groundwater (Fig. 3c) are very similar to the lake level trend, confirming the direct connection between the lake and the phreatic aquifer, but groundwater temperature remains significantly more stable within a limited range from about $12{ }^{\circ} \mathrm{C}$ to about $15^{\circ} \mathrm{C}$.

\section{Objective of the study and methodology}

The fundamental objective of the study is the hydraulic parameterization of the aquifer, implementing a numerical model to estimate the influence of the abstraction wells and to evaluate the hydrogeological sustainability of the new pumping station. Below is a brief summary of the applied methodology:

1. preliminary steps:

a. numerical model to calculate the expected drawdown during the following pumping tests;

b. analytical interpretation of the pumping tests to obtain punctual values of hydraulic conductivity;

2. pilot points calibration of the numerical model using groundwater level measurements, to identify the possible parameter fields;

3. simulation of heat transfer between the lake and the aquifer, using groundwater temperature time series to calibrate the hydraulic conductivity distribution.

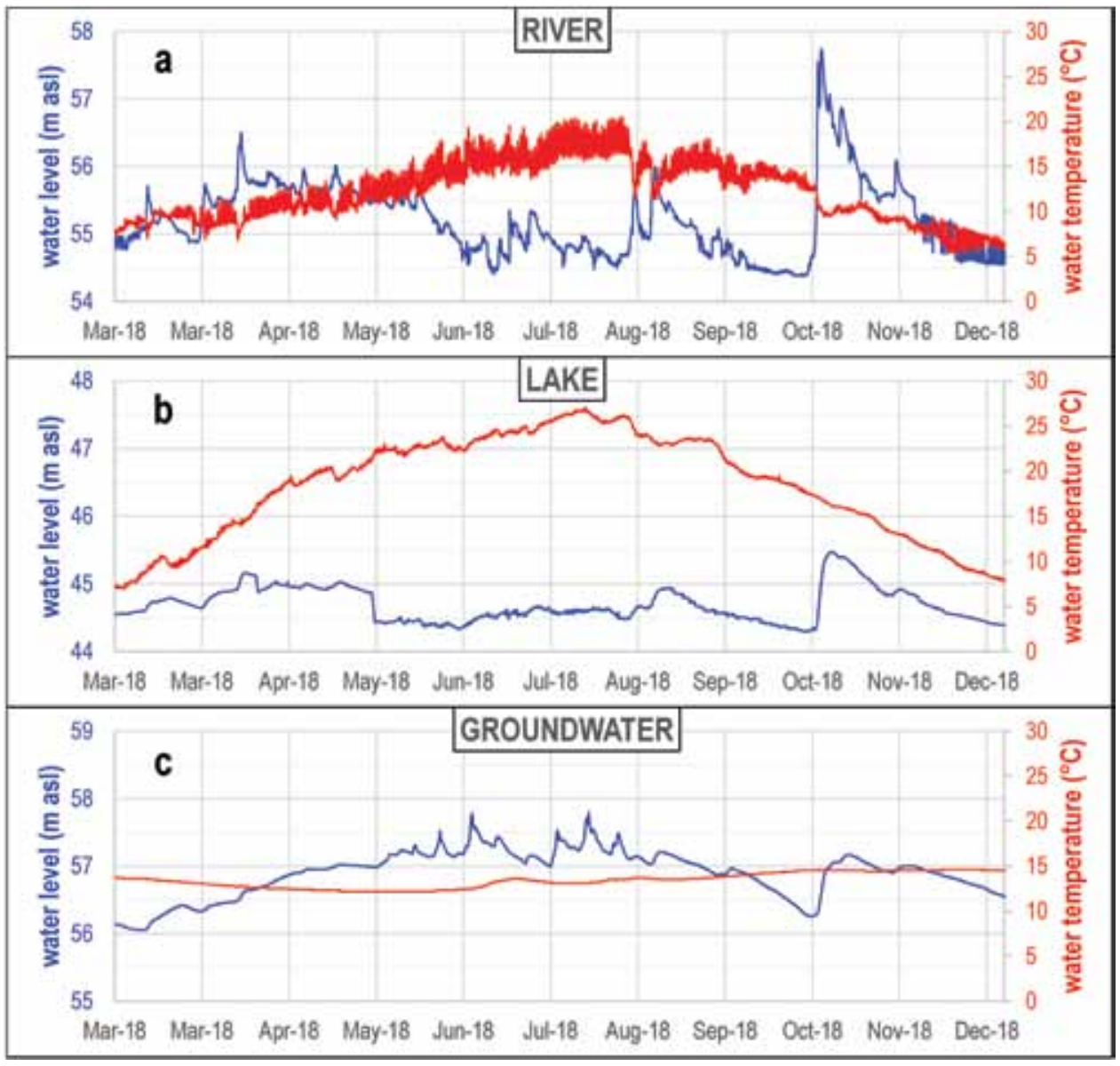

Fig. 3 - Water level and temperature monitored trends in river (a), lake (b) and groundwater (c).

Fig. 3 - Andamenti monitorati di livello e temperatura nel fiume (a), nel lago (b) e in falda (c). 


\section{Preliminary model and pumping tests}

In order to plan the following field activities and to estimate the expected drawdown of the pumping tests, an initial numerical model was needed, even though no experimental information was available to validate the simulation reliability. So, according to bibliographic data, the phreatic aquifer was represented as a bidimensional isotropic unit, assuming a homogeneous parameter distribution with a constant value of hydraulic conductivity ( $\mathrm{K}=6 \mathrm{E}-03 \mathrm{~m} / \mathrm{s})$ assigned to the entire mesh. This value was obtained from a pumping test, performed in wells intercepting the saturated layer. Such pumping test seemed to be averagely representative for the gravelly material the aquifer is made of.

The model was implemented with the finite element numerical code FEFLOW (Diersch 2014) and a transient simulation was setup to define the optimal pump rates to be used during the field tests, to estimate the expected drawdown in the phreatic aquifer and, consequently, the maximum extension of the zone of influence of the new pumping wells. Calculated values of maximum drawdown were then compared to pumping test observations at the highest abstraction rate, an overall value of about $1.3 \mathrm{~m}^{3} / \mathrm{s}$, as shown in Figure 4a.

A maximum residual of $0.13 \mathrm{~m}$, a mean absolute error of $0.054 \mathrm{~m}$ and a normalized RMS error of $12.53 \%$ were calculated comparing observed and estimated drawdown values, with an overall observation range of $0.53 \mathrm{~m}$. According to these results, the preliminary model is considered an efficient tool to provide a first estimate of the hydraulic effects caused by the new abstraction wells. The relative success of the prediction depended exclusively on the representativeness of the hydraulic conductivity value initially assumed for the numerical model, substantially confirmed by the new values obtained with the analytical interpretation of the pumping tests, ranging from $3.7 \mathrm{E}-03 \mathrm{~m} / \mathrm{s}$ to $1.7 \mathrm{E}-02 \mathrm{~m} / \mathrm{s}$ (Table 1); pumping and observation wells are mapped in Figure $4 \mathrm{~b}$.

These results have been obtained through the interpretation of several step drawdown and constant rate pumping tests in the new wells, progressively activated with different configurations, recording water level and temperature with dataloggers in 12 observation wells, 2 monitoring stations in the river and 1 installed in the lake.

Tab. 1 - Pumping tests results.

Tab. 1 - Risultati delle prove di pompaggio.

\begin{tabular}{|l|l|l|}
\hline Pumping well & Observation wells & $\begin{array}{c}\text { Hydraulic conductivity } \\
(\mathrm{m} / \mathbf{s})\end{array}$ \\
\hline P12 & P12 & $3.7 \mathrm{E}-03$ \\
\hline P13 & PzB, PzC & 5.8 E-03 \\
\hline P14 & PzC, Pz2H & $5.1 \mathrm{E}-03$ \\
\hline P15 & P16, PzE & $1.2 \mathrm{E}-02$ \\
\hline P16 & P15, P17, P18 & $1.1 \mathrm{E}-02$ \\
\hline P17 & P18, BH3 & 1.0 E-02 \\
\hline P18 & Pz11, P19, BH3 & 1.7 E-02 \\
\hline P19 & BH3, Pz11 & 1.2 E-02 \\
\hline
\end{tabular}

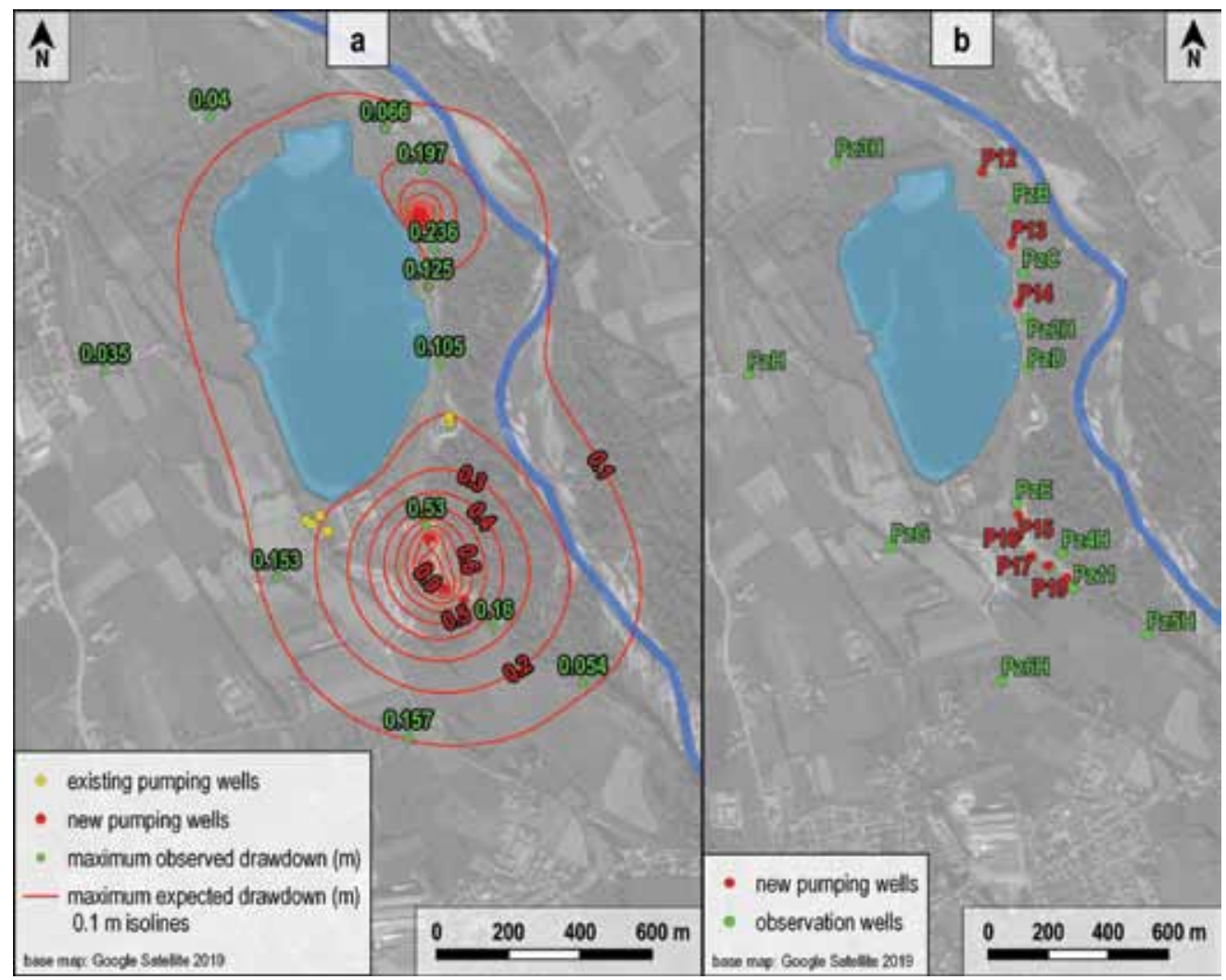

Fig. 4 - Initial model estimation compared to following pumping test observations (a); name and location of pumping and observation wells (b).

Fig. 4 - Stima del modello iniziale confrontata con le osservazioni della successiva prova di pompaggio (a); nome e ubicazione dei pozzi di pompaggio e osservazione (b). 


\section{Pilot points calibration}

Next step was to define a spatial distribution for the punctual values of hydraulic conductivity, in order to improve initial model parameterization. The availability of groundwater level measurements, performed every three months in 67 observation points, allowed to extend the numerical model validation on a wider domain of $37.2 \mathrm{~km}^{2}$, with a mesh made of about 255,000 triangle elements, refined at wells locations and at the interfaces among the river, the lake and the phreatic aquifer (Figure 5).

Dirichlet boundary conditions were assigned along north and south mesh boundaries (hydraulic head values of $56 \mathrm{~m}$ asl and $35 \mathrm{~m}$ asl were specified along the north and south boundaries, respectively) and no flow conditions were imposed at west and east boundaries. The river was simulated with a Cauchy boundary condition, assigning water level values derived from monitoring data (ranging from about $58 \mathrm{~m}$ asl in the north and $37 \mathrm{~m}$ asl in the south) and calibrating riverbed hydraulic conductance. The lake was represented in the model assigning very high values of hydraulic conductivity to the corresponding mesh elements and calibrating lakebed hydraulic conductance.

A series of steady state flow simulations was implemented, calibrating all the available groundwater level datasets, for a total of 8 measurement campaigns, with PEST (Doherty,

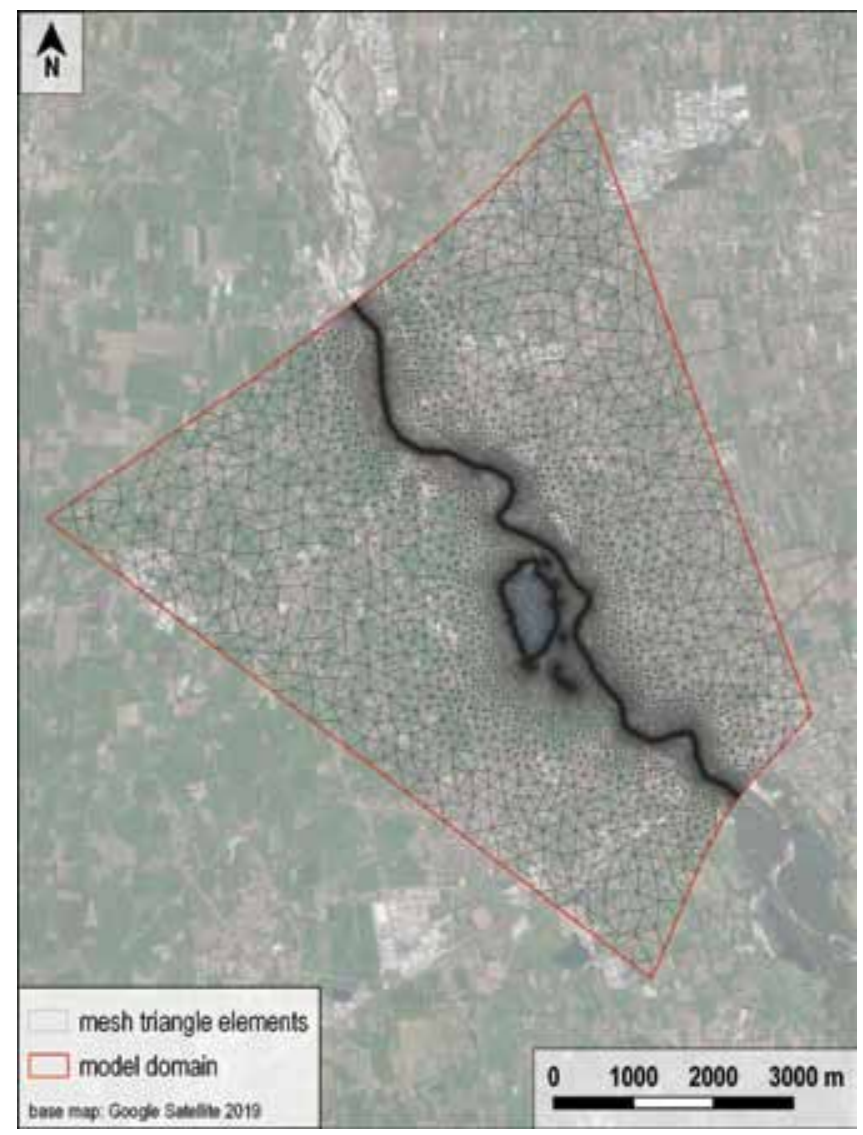

Fig. 5 - Finite element model mesh.

Fig. 5 - Mesh del modello a elementi finiti.
2018); using the pilot points method, several optimized hydraulic conductivity fields were obtained. These realizations were then compared, identifying the areas with the highest variability for the estimated hydraulic conductivity and selecting the solutions providing the best fit with all the available experimental observations. One of the selected interpolations is represented in Figure 6, with hydraulic conductivity values ranging from $1 \mathrm{E}-04 \mathrm{~m} / \mathrm{s}$ to $3 \mathrm{E}-02 \mathrm{~m} / \mathrm{s}$ for the simulated phreatic aquifer; the statistics about the overall calibration on all the different hydraulic head datasets are listed in Table 2.

\section{Heat transport simulation}

The monitoring network has been kept in operation since March 2018, collecting water level and temperature data series in 20 monitoring stations, with a 1-hour recording interval. The availability of water temperature time series, acquired by dataloggers in parallel with hydraulic head values, allowed to implement a heat transport model. By means of this simulation, it was possible to calibrate the hydraulic conductivity of the lakebed and the aquifer, reproducing the temperature variations observed at the monitoring wells

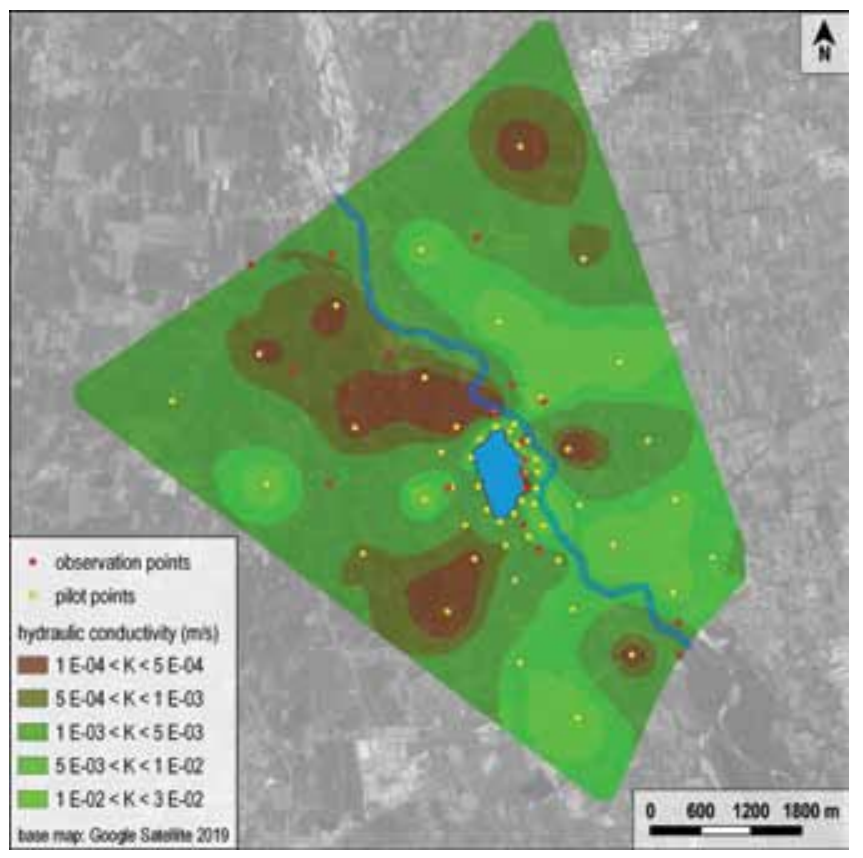

Fig. 6 - Hydraulic conductivity distribution obtained with pilot points calibration.

Fig. 6 - Distribuzione della conducibilità idraulica ottenuta tramite la calibrazione con pilot points.

Tab. 2 - Pilot points calibrations results.

Tab. 2 - Risultati delle calibrazioni con pilot points.

\begin{tabular}{|l|c|c|c|}
\cline { 2 - 4 } \multicolumn{1}{c|}{} & $\begin{array}{c}\text { Absolute error } \\
(\mathrm{m})\end{array}$ & $\begin{array}{c}\text { RMS error } \\
(\mathrm{m})\end{array}$ & $\begin{array}{c}\text { Normalized } \\
\text { RMS error }\end{array}$ \\
\hline Minimum & 0 & 0.125 & $0.58 \%$ \\
\hline Mean & 0.159 & 0.2 & $0.9 \%$ \\
\hline Maximum & 0.638 & 0.264 & $1.24 \%$ \\
\hline
\end{tabular}


near the lake. Dirichlet boundary conditions were assigned also for temperature, whose values were defined according to monitored time series, in order to simulate the heat transfer from the lake and to reproduce the temperature trend of the groundwater flowing into the model from the northern boundary. Another PEST calibration was conducted, using pilot points for the aquifer and a discrete zonation to characterize the lake-groundwater interface.

The main downside of applying a transport model is the increase in the number of parameters to be considered, for which no experimental data were available. Hydraulic conductivity and heat dispersivity resulted to be the most sensitive parameters for groundwater driven heat transport simulations. As such, assuming a uniform value of dispersivity, the calibration process still focused on the hydraulic conductivity distribution, both in the lakebed and in the aquifer, reaching a more detailed and refined parameter assignment in the area between the lake and the observation wells. This method leaded to a much better simulation of the lake-aquifer flow exchanges, with a direct influence on the estimation of pumping wells drawdown and capture areas. In particular, a lakebed clogging effect had to be represented in the model, in order to obtain a good fit with observed temperature time series; especially along the south border of the lake, where the main groundwater recharge occurs, the calibrated hydraulic conductivity resulted relatively low (from
$8 \mathrm{E}-06 \mathrm{~m} / \mathrm{s}$ to $1 \mathrm{E}-04 \mathrm{~m} / \mathrm{s}$ ) when compared to aquifer values. This could be interpreted as a consequence of a historical deposition of fine materials on the interface layer.

The heat transport calibration results are displayed in Figure 7, comparing observed temperature trends with calculated values.

Monitoring wells locations are shown in Figure 8, with a contour map of the thermal plume generated by the lake at the peak summer temperature $\left(27.1^{\circ} \mathrm{C}\right.$ measured on 9 August 2018), showing groundwater temperature isolines from 15 ${ }^{\circ} \mathrm{C}$ to $25{ }^{\circ} \mathrm{C}$. The numerical model was then recalibrated with hydraulic head observations, in order to optimize the hydraulic conductivity distribution both for steady state (flow) and transient (heat transport) simulations.

\section{Conclusions}

Sustainable management of groundwater resources must be based on an accurate knowledge of the natural systems exploited for water supply, specifically regarding aquifer hydraulic properties. In this case study, the traditional parameterization method, based on pumping tests interpretation and hydraulic head calibration, was improved with a numerical simulation of the heat exchange between a lake and the surrounding groundwater. By applying this methodology, it was possible to estimate the lakebed conductance and to validate the

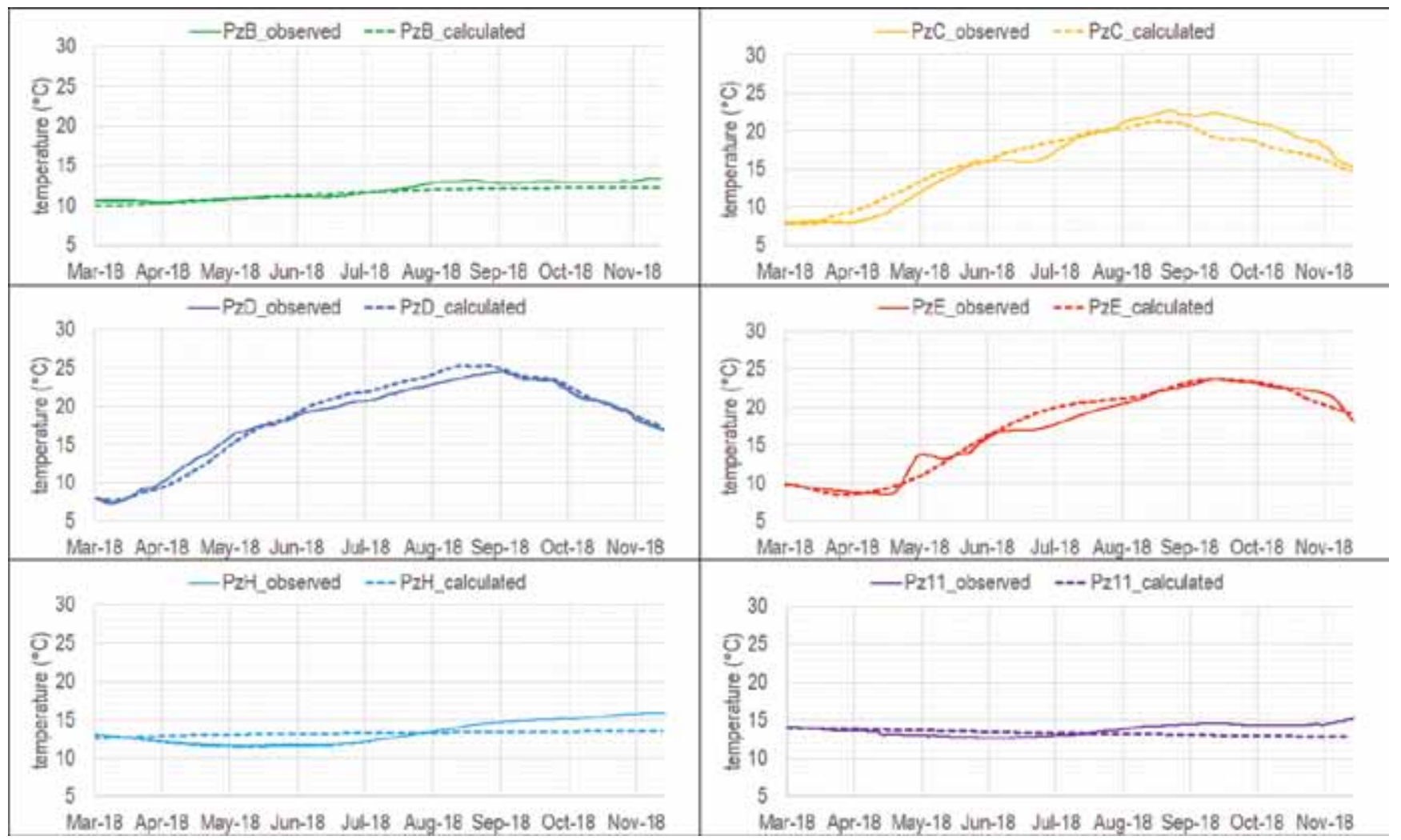

Fig. 7 - Comparison between observed and calculated temperature time series.

Fig. 7 - Confronto tra serie di dati di temperatura osservati e calcolati. 
hydraulic conductivity distribution of the aquifer, with different types of observations, directly available from the same dataloggers used for groundwater level monitoring.

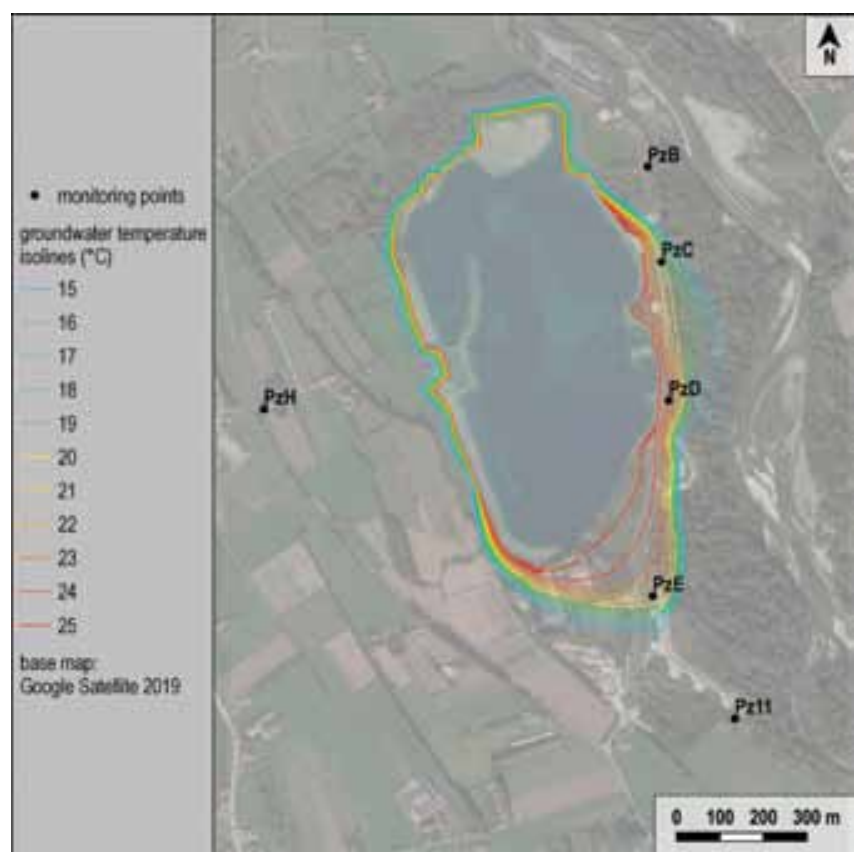

Fig. 8 - Hot water plume generated by the lake at peak temperature.

Fig. 8 - Plume di acqua calda generato dal lago alla temperatura di picco.

\section{REFERENCES}

Anderson, M. P. (2005), Heat as a Ground Water Tracer. Groundwater, 43: 951-968. doi: 10.1111/j.1745-6584.2005.00052.x.

Bravo, H. R., F. Jiang, and R. J. Hunt (2002), Using groundwater temperature data to constrain parameter estimation in a groundwater flow model of a wetland system, Water Resour. Res., 38(8). doi: 10.1029/2000WR000172.

Constantz, J. (2008), Heat as a tracer to determine streambed water exchanges, Water Resour. Res., 44, W00D10. doi: 10.1029/2008WR006996.

Constantz, J. and Stonestrom, D.A. (2003), Heat as a Tracer of Water Movement near Streams. U.S. Geological Survey Circular, No. 1260, 1-96.

Dal Prà, A. (1999), Valutazione degli effetti sulla falda determinati dalla cava Giaretta ubicata nella località Boschi di Camazzole in golena destra del Brenta. Consorzio di bonifica Pedemontano Brenta, Cittadella (Padova).

Diersch, H.-J.G. (2014), FEFLOW - Finite Element Modeling of Flow, Mass and Heat Transport in Porous and Fractured Media. doi: 10.1007/978-3-642-38739-5.

Doherty, J. (2018), PEST, Model-Independent Parameter Estimation - User Manual. 7th Edition, Watermark Numerical Computing, Brisbane.

Doherty, J. (2015), Calibration and Uncertainty Analysis for Complex Environmental Models. Watermark Numerical Computing, Brisbane, Australia. ISBN: 978-0-9943786-0-6.

Hunt, R. J., D. P. Krabbenhoft, and M. P. Anderson (1996), Groundwater Inflow Measurements in Wetland Systems, Water Resour. Res., 32(3), 495-507. doi: 10.1029/95WR03724.

Moench, A.F., Garabedian, S.P., and LeBlanc, D.R. (2001), Estimation of hydraulic parameters from an unconfined aquifer test conducted in a glacial outwash Deposit, Cape Cod, Massachuesetts. US Geol. Survey Professional Paper 1629.

Kruseman, G.P. and N.A. DeRidder (1990), Analysis and Evaluation of Pumping Test Data (2nd ed.), Publication 47, Intern. Inst. for Land Reclamation and Improvement, Wageningen, The Netherlands, 370p.

Su G. W., Jasperse J., Seymour D., Constantz J. (2004), Estimation of Hydraulic Conductivity in an Alluvial System Using Temperatures. Groundwater, 42: 890-901. doi: 10.1111/j.1745-6584.2004.t01-7-.x.

Sudicky, E.A. (1986), A natural gradient experiment on solute transport in a sand aquifer: Spatial variability of hydraulic conductivity and its role in the dispersion process. Water Resources Research 22, 2069-2082.

Zhang, Y., Person, M., and Gable, C.W. (2007), Representative hydraulic conductivity of hydrogeologic units: Insights from an experimental stratigraphy. Journal of Hydrology 339, 65-78 